rate from 97 to 69 . The toll of sickness upon industry remains, however, very great, for expenditure on benefits under National Health Insurance amounted in 1937 to $£ 28,000,000$, but hundreds of firms to-day are safeguarding the health of their staffs.

\section{Earthquakes Registered at European Observatories}

Four earthquakes of considerable severity have been registered by seismographs in Europe recently. The first, on April 28, was registered at De Bilt (Holland) at 0 h. 38m. 15s. G.C.T. and may have been distant a little more than $24^{\circ}$. The second caused the needle on a seismograph in London to swing about $3 / 5$ in. It was recorded at De Bilt on April 30 at $3 \mathrm{~h} .12 \mathrm{~m}$. 0s. G.C.T., and at Uccle at $3 \mathrm{~h} .12 \mathrm{~m}$. 12s. Since the epicentral distance was greater than $100^{\circ}$, observations are awaited from more distant observatories before further computations are made. The third was on May 1, and this is discussed below, being the most important of the four. The fourth was recorded at Kew on May 2 at 13h. 27m. 12s. and may have been an aftershock of the one on the previous day, though a slightly nearer epicentre may be indicated.

\section{Japanese Earthquake of May I}

RECORDs of this earthquake have been reported by the following observatories:

$\begin{array}{ll}\text { De Bilt } & \text { at } 6 \mathrm{~h} .10 \mathrm{~m} .42 \mathrm{~s} . \text { G.C.T. } \\ \text { Strasbourg } & \text { at } 6 \mathrm{~h} .10 \mathrm{~m} .47 \mathrm{~s} \text { G.C.T. } \\ \text { Ucele } & \text { at } 6 \mathrm{~h} .10 \mathrm{~m} .47 \mathrm{~s} \text {. G.C.T. } \\ \text { Kew } & \text { at } 6 \mathrm{~h} .10 \mathrm{~m} .52 \mathrm{~s} \text {. G.C.T. } \\ \text { with an aftershock. } & \text { at } 6 \mathrm{~h} .12 \mathrm{~m} \text {. 32s. G.C.T. }\end{array}$

The epicentre distance from all these stations was between $80^{\circ}$ and $83^{\circ}$ and the evidence points to an epicentre in the neighbourhood of the Oga Peninsula north-west of Akita, a town on the north-west coast of the main island of Japan. Possible epicentral co-ordinates are lat. $39 \cdot 8^{\circ} \mathrm{N}$., long. $139 \cdot 9^{\circ} \mathrm{E}$. The shock occurred at 2.59 p.m. local time and lasted 27 seconds. It caused strong vertical movement locally and there was a considerable amount of surface faulting. In the Oga Peninsula the faulting caused land to slide into the sea, and wrecked many houses. In Akita itself plate glass windows were shattered and shop fronts fell out. The reservoir at Funakawa is reported to have burst its banks and drowned three people. Altogether twenty-six people were killed and thirty-eight injured and many slept out in the open that night. Fortunately, the resulting fires were quickly extinguished by the fire brigades, though railway and telegraph communications were disturbed. Aftershocks were frequent locally for some time and some of these were of considerable severity as the Kew records indicate.

\section{The Colonial Service: Recent Appointments}

Tre following appointments and promotions in the Colonial Service have recently been made: R. H. A. Merlen, veterinary officer, Gold Coast; E. Burtt, junior entomologist, Sleeping Sickness Research Station, Tanganyika Territory; A. E. Pound, inspector of plants and produce, Gold Coast; G. H. Swynnerton, game ranger, Tanganyika Territory; R. B. Warner, inspector of produce, Nigeria ; G. J. L.
Burton (senior plant breeder and experimentalist), chief research officer, Agricultural Department, Kenya ; G. Griffith (assistant agricultural chemist, Uganda), chemist (soils), Malaya; G. R. Spurrell, (inspector of plants and produce), agricultural superintendent, Gold Coast; Dr. G. J. Williams (assistant geologist, Tanganyika Territory), geologist, Gold Coast; R. G. Newberry (schoolmaster), agricultural education officer, Agricultural Department, Nigeria; W. H. Reeve (late assistant field geologist, Tanganyika Territory), geologist, Nyasaland.

\section{Announcements}

Sir Charles Vernon Boys has been awarded the Elliot Cresson Gold Medal of the Franklin Institute, in recognition of his scientific achievements, "which have furnished scientists with new and remarkably precise methods for making measurements in gravitation, in sound, in heat, in radiation, in current and static electricity, so refined as to render possible the weighing of the earth, the determination of the radiant energy conaing to us from the stars, the photography of the speeding bullet and the immobilization, even, of the lightning flash itself'". The medal will be presented on May 17.

The Chalmers Gold Medal of the Royal Society of Tropical Medicine and Hygiene has been awarded to Dr. Max Theiler of the International Health Division of the Rockefeller Foundation, New York. The medal has been awarded to Dr. Theiler in recognition of research of outstanding merit in tropical medicine or tropical hygiene particularly in reference to yellow fever, and the possibility of producing the vaccine by the use of attenuated virus.

The twenty-fifth French Congress of Social Hygiene will be held at the Bordeaux Faculty of Medicine under the presidency of Dr. George Risler on May 19-21. Further information can be obtained from L'Alliance d'Hygiêne Sociale, 5 rue Las Cases, Paris.

AN International Meeting on Physics is being arranged during September 4-16 by the Federal Institute of Technology and the Physical Society of Zurich in connexion with the Swiss National Exhibition which was opened by the President of the Swiss Confederation on May 6. The meeting will be divided into five sections, dealing with nuclear physics, physies of the solid body, technical physics, television and high-frequency studies, respectively. Leading scientific workers in these subjects from all parts of the world are taking part. Further particulars can be obtained from the Secretary, International Meeting on Physics, 4l Gloriastrasse, Zurich 7.

The English Universities Press, Ltd., Little Paul's House, Warwick Square, London, E.C.4, is organizing a competition for schools in the form of question papers on three of its recently published books : "Man against Microbe", "Physical Science in Modern Life" and "Ascaris : the Biologist's Story of Life". The age limit is nineteen years and the competition closes on July 31. Particulars can be obtained from the English Universities Press, Ltd. 